\title{
Reproductive performance of Bhagnari cattle breed managed under semi- intensive management condition
}

\author{
Hamzo Khan Kunbhar*, Syed Muhammad Sharif, Akeel Ahmed \\ Memon, Shahid Hussain Abro, Rani Abro, Velaram Suthar and Gulfham \\ Ali Mughal \\ Faculty of Animal Husbandry and Veterinary Sciences, Sindh Agriculture University Tandojam, Sindh, Pakistan \\ *Corresponding author's e-mail: drkunbhar@gmail.com
}

Citation

Hamzo Khan Kunbhar, Syed Muhammad Sharif, Akeel Ahmed Memon, Shahid Hussain Abro, Rani Abro, Velaram Suthar and Gulfham Ali Mughal. Reproductive performance of Bhagnari cattle breed managed under semi-intensive management condition. Pure and Applied Biology. Vol. 5, Issue 3, pp615-621.

http://dx.doi.org/10.19045/bspab.2016.50080

\begin{tabular}{llll}
\hline \hline Received: 24/02/2016 & Revised: 06/06/2016 & Accepted: 15/06/2016 & Online First: 21/06/2016 \\
\hline \hline
\end{tabular}

\section{Abstract}

The study was conducted on reproductive performance of Bhagnari cattle maintained under semiintensive management condition at Usta Mohammad Cattle Farm, Baluchistan. The data was collected on eighty four adult Bhagnari cows, selected on the performance record and utilized for this study. The results revealed that the mean age at puberty was recorded as $1154.179 \pm 53.48$ days and age at first calving was $1462.024 \pm 59.38$ days. The calving interval was recorded as $437.59 \pm 16.91$ days, service period $158.71 \pm 17.01$ days and postpartum estrus period $135.94 \pm 11.87$ days. The mean milk yield was recorded $785.78 \pm 14.53$ liters per cow, which was increased from first to $4^{\text {th }}$ lactation. The calving intervals, service period and post-partum estrus was found decreased from $1^{\text {st }}$ to $5^{\text {th }}$ parity. The difference between the parity was non-significant $(\mathrm{P}>0.005)$ for calving interval, postpartum period, service period and milk yield. The reproductive performance and milk yield was found very low, which needs to be improved by improving management practices and out-crossing or cross breeding program on scientific line.

Key words: Cattle, Bhagnari breed, Reproductive Performance, Semi-Intensive-management

Introduction

Pakistan is endowed with a large livestock population. The national herd consists of 39.7 million heads of cattle, 34.6 million buffaloes, 29.1 million sheep and 66.6 million goats [1]. Pakistan is the $3^{\text {rd }}$ largest milk producer country in the world $[2,3]$. The $60.78 \%$ of milk production comes from buffalo; while cattle are producing $35.06 \%$ and remaining $4.16 \%$ of milk is contributed by sheep, goats and camels [1]. In the past, cattle were kept for draught purpose. Later, with the industrialization, the cattle occupied the place of dairy and meat animal [4]. In Pakistan, there are more than ten distinct cattle breeds among those Red Sindhi, Sahiwal, Thari, Dhajal and Bhagnari are most popular cattle breeds [5]. The Bhagnari is a beef and draught breed, found in Bhag territory in north of district Jacobabad, Sindh and Sibi district of Baluchistan. Its name probably reflects its origin from Tehsil Bhag 
near Sibi, Baluchistan. The Bhagnari cattle have the ability to survive in hard environmental conditions and have resistance power against various diseases as compared to exotic cattle breeds [6]. The reproduction and production are directly influenced by genetic potential of the animals, nutrition, environment, management of farm and staff involved [7]. Under optimal condition a cow heifer should attained puberty at an early age, conceive to fertile mating, produce a viable calf, return to estrus early after calving and again become pregnant and repeat this cycle at regular interval till the end of its productive life [7]. This process insures a harvest of more milk and calf crops during the life time of animal. A delay at any stage causes great economic losses to the livestock farmers [7]. Most of the cows are low producers due to nutritional imbalance, inadequate management practices, lack of timely breeding, poor estrus detection; which causing long calving intervals, increased post-partum period, service period and reduced fertility rate in general and in cattle breed of Baluchistan province in particular $[5,7]$. Though some work has been carried out to assess the reproductive performance of Red Sindhi, Sahiwal and other local cattle breeds, but Bhagnari is concerned received very little attention in the past. This study is therefore designed to investigate and collect information on reproductive performance of Bhagnari cattle breed managed under semiintensive management condition.

\section{Materials and methods}

The study was conducted on 84 Bhagnari cows maintained under semi-intensive management conditions at Usta Mohammad Cattle Farm, Baluchistan. The data was obtained from the record available at the farm and utilized for this study. The animals were placed in tail to tail management system. The cows were milked twice a day (morning and evening); hand milking was practiced at the farm. Lactating, advanced pregnant, young calves, heifers and breeding bulls were categorized and kept in separate sheds. Natural breeding was practiced at the farm. Vaccination and deworming were adopted at the farm as per scheduled. Wheat straw, seasonal green fodders and concentrates (wheat bran, rice bran and cotton seed cake) were given in portions twice a day and common salt blocks were placed in the mangers. The animals were free access to fresh water round the clock. The data were recorded in a separate proforma specially designed for this purpose.

\section{Parameters studied}

\section{Age at puberty}

Puberty was considered as the time from birth to showing estrus for first time.

\section{Age at first calving}

It was computed as the time period between date of birth and first calving.

Calving interval Intervals between two successful calving.

Service period: The interval from parturition to fruitful mating.

\section{Postpartum estrus}

Interval from parturition to appearance of estrus for first time after calving.

\section{Milk yield}

Whole lacteal secretion free from colostrum obtained by complete milking.

\section{Statistical analysis}

The data were Analyzed Statistically using Standard Statistical method T-test, Variance and Standard Deviation.

\section{Results and discussion}

\section{Age at puberty}

Puberty is the process of acquired development of reproductive competency. The mean age at puberty was recorded as $1154.179 \pm 53.48$ days in Bhagnari cows (Table-1). The results recorded in present study for age of puberty are in accordance to the results reported (720 to 1024 days) in Red Sindhi and Bhagnari cattle breed $[8,9]$. The findings of current study fall within the rage (1350 day) reported for indigenous and 
crossbred cattle $[10,11]$. The results recorded in present study for age at puberty were shorter (540 to 987 days) than the results reported by various authors in Holstein Friesian and Jersey cattle $[12,13]$. The age at puberty of local Pakistani cattle breeds was higher than the European cattle breeds [14, 15]. The delayed age at puberty observed in

Table 1. Age at puberty, age at first calving and calving intervals in Bhagnari cattle

\begin{tabular}{|l|l|l|l|}
\hline Variable/Parameters & No of observation & Mean( $\mathbf{S E M})$ days & Range (days) \\
\hline Age at puberty & 84 & $1154.179 \pm 53.48$ & $542-1667$ \\
\hline Age at first calving & 84 & $1462.024 \pm 59.38$ & $818-1945$ \\
\hline Calving intervals & 294 & $437.59 \pm 16.91$ & $333-863$ \\
\hline
\end{tabular}

\section{Age at first calving}

The life time production depends upon the age at first calving. Shorter the age at first calving causing increase in life time production both in calf crop and milk production. In the present study the mean age at first calving was recorded as 1462.024 \pm 59.38 days in Bhagnari cows (Table-1). The results of present study falls in the range to those reported from 763-2150 days in indigenous cows [10], 420 to 1620 in crossbreed cows [11] and 524 -1827 days in Bhagnari cattle [9]. The results of current study falls in the close range with little variation between 1235 to 1345 days in Sahiwal cattle [16] and 1120 to 1345 days in Red Sindhi cattle [8, 17]. The results of current study are higher than the figures (701 to 987 days) reported in Holstein Friesian cattle [13]. The age at first calving was reduced up to 963 to 1020 days, when Holstein Friesian cows crossed with Zebu and Sahiwal cows [14, 15]. In the present study the age at first calving was found higher, which was possibly due to genetic factor, low nutrition plan, poor management and environmental condition.

\section{Calving interval}

One calf per year is considered to be highly profitable primary achievement in cattle farming. Shorter the calving interval, higher would be the chance of profitable farming present study may be due to the genetic factors, climate, malnutrition and poor managemental practices at the farm. The age at puberty can be reduced by crossing the local breed animals with the exotic breeds or out crossbreeding with selected animals. business. The mean calving interval was recorded as $437.59 \pm 16.91$ days. It was slightly decreased from $1^{\text {st }}$ to $5^{\text {th }}$ calving in Bhagnari cattle. The results were significantly difference ( $>0.05)$ among the various parity for calving interval in Bhagnari cattle (Table-1 \&2). The results obtained in present study are in close agreements to those reported from 429 to 515 days in Red Sindhi cattle [7, 17] and 397 to 473 days in Sahiwal cattle breed and crosses of Holstein Friesian cattle [13, 16]. However a shorter calving interval (388 to 450 days) was reported in Holstein Friesian cows as compared to the finding of present study $[12,13]$ and similar trend was also reported (414 days) in Holstein Friesian cross with Sahiwal cows, when maintained at Okara Punjab Pakistan [16] and slightly shorter (379 to 444 days) calving interval was reported for Simmental and Sanga cows [19, 20]. In contrast to this a longer calving interval of 540 days was reported in Red Sindhi and Holstein Friesian cattle [14, 16] and 612 in indigenous cattle breeds [10]. A Long calving interval found in present study could be due to the hot summer, heat stress and reduced feed intake due to hot weather that causing increase in water losses and mineral imbalance that may cause depressed and weak estrus signs and ovarian activity in Bhagnari cattle. 
Table 2. Mean $\left( \pm\right.$ SEM) calving interval from $1^{\text {st }}$ to $5^{\text {th }}$ calving in Bhagnari cattle

\begin{tabular}{|l|l|l|l|}
\hline Parity & No. of cows observed & $\begin{array}{l}\text { Calving Interval (days) Mean } \\
( \pm \text { SEM })\end{array}$ & Range (days) \\
\hline Calving-1 & 84 & $520.12 \pm 12.676 \mathrm{a}$ & $335-663$ \\
\hline Calving -2 & 82 & $465.66 \pm 12.830 \mathrm{~b}$ & $345-625$ \\
\hline Calving -3 & 64 & $442.95 \pm 14.522 \mathrm{~b}$ & $336-602$ \\
\hline Calving -4 & 46 & $380.93 \pm 17.130 \mathrm{c}$ & $336-557$ \\
\hline Calving-5 & 18 & $370.89 \pm 27.383 \mathrm{c}$ & $333-467$ \\
\hline Total average & 294 & $437.59 \pm 16.91$ & $333-663$ \\
\hline
\end{tabular}

\section{Service period}

The mean service period was recorded as $158.71 \pm 17.014$ days, which was ranged from 56 to 487 days and it was decreased from $1^{\text {st }}$ to $5^{\text {th }}$ parity. Analysis of variance showed a significant difference $(p>0.05)$ between the parity for the service periods in Bhagnari cattle (Table-3). The results recorded for services period in present study were in close agreements with the results reported as 155 days in Sahiwal cattle [16] and 156.48 days in Bhagnari cattle [9]. The similar trend was reported as 151 days in Jersey [12], 153 days in Sanga [21] and 167.26+9599 days in indigenous cows of Azad Kashmir [10].

Table 3. Mean $( \pm$ SEM) service period in Bhagnari cattle

\begin{tabular}{|l|l|l|l|}
\hline Parity & No. of cows observed & $\begin{array}{l}\text { Service period (days) } \\
\text { Mean }( \pm \text { SEM) }\end{array}$ & Range (days) \\
\hline Service-1 & 84 & $191.06 \pm 12.637 \mathrm{a}$ & $56-487$ \\
\hline Service -2 & 82 & $164.02 \pm 12.790 \mathrm{~b}$ & $70-447$ \\
\hline Service -3 & 64 & $144.78 \pm 14.477 \mathrm{~b}$ & $60-418$ \\
\hline Service -4 & 46 & $137.54 \pm 17.076 \mathrm{~b}$ & $90-368$ \\
\hline Service -5 & 18 & $154.18 \pm 28.090 \mathrm{c}$ & $60-189$ \\
\hline Total average & 294 & $158.71 \pm 17.014$ & $56-487$ \\
\hline
\end{tabular}

\section{Postpartum estrus period}

The post-partum estrus period start from calving and lasts until uterine involution is completed and the female animal has resumes regular estrus cycle. Normally it ranges from 42-90 days, but some of the cow may ovulate around the day $21^{\text {th }}$ after calving, without showing any signs of estrus. Behavioral signs of estrus cannot be established before 42 days of calving [14]. The mean postpartum estrus period was
However, shorter service period was reported, which was ranged between 94 and 124 days in Simmental cows [19], whereas similar trend (135 and 139 days) was reported in the cross breed and Red Sindhi cows [7, 17]. In contrast to this a longer service period was reported as 222.22 days in Holstein Friesian cows [13] and 235.87 \pm 14.05 days in Red Sindhi cattle $[7,8]$. The longer service period may be due to that, because of these animal were kept for dairy purpose and owners were interested only in receiving milk production, their lack of interest in rebreeding caused the longer service period. 
the figures (24-76 days) reported in Zebu cattle and (88 days) in Sanga cows [14, 19], whereas with little variation (90 to 105 days) in Red Sindhi cattle $[7,17]$. A slightly higher results than the finding of present study were reported as $177.1 \pm 12.5$ days for postpartum estrus period in cross breed cattle [21].
Similar trend (152 days) was reported in Sanga cattle [20]. However in present study, the postpartum estrus period was observed delayed as compared to some other breeds this may reflect the poor nutrition and poor management at the farm, breed and genetic factor of the breed.

Table 4. Mean $( \pm$ SEM) postpartum estrus period in Bhagnari cattle

\begin{tabular}{|l|l|l|l|}
\hline Parity & $\begin{array}{l}\text { No. of cows } \\
\text { observed }\end{array}$ & $\begin{array}{l}\text { Post-partum estrus(days) } \\
\text { Mean }(\mathbf{\pm S E M})\end{array}$ & Range (days) \\
\hline Postpartum-1 & 84 & $150.50 \pm 8.884 \mathrm{a}$ & $56-207$ \\
\hline Postpartum-2 & 82 & $138.72 \pm 8.992 \mathrm{~b}$ & $49-192$ \\
\hline Postpartum-3 & 64 & $124.94 \pm 10.178 \mathrm{~b}$ & $60-174$ \\
\hline Postpartum-4 & 46 & $135.58 \pm 12.138 \mathrm{~b}$ & $42-126$ \\
\hline Postpartum-5 & 18 & $132.44 \pm 19.192 \mathrm{~b}$ & $64-164$ \\
\hline Total average & 294 & $135.269 \pm 10.876$ & $42-1172$ \\
\hline
\end{tabular}

\section{Milk yield}

Milk and milk byproducts are the single largest commodity which supply much needed quality proteins, minerals and vitamins to the human family. The average milk yield was recorded as $785.78 \pm 14.53$ liters. The analysis of variance showed a significant $(\mathrm{p}>0.05)$ difference between the lactations in Bhagnari cows (Table-5). The results reported in Red Sindhi cattle and in Sahiwal cattle $[7,17,22]$ were higher than the findings of current study. The milk yield reported in some indigenous beef and draught cattle breeds i.e. Thari (1140) and Colistani (1235) were also higher than the figures observed in current study $[10,14]$. However higher milk yield than the present study was reported in Holstein Friesian cows by many scientists $[13,14,18]$. Improvement in the milk yield was recorded up to 1385 to 2064 liters, when Red Sindhi cows crossed with Holstein Friesian cows [7, 18]. The findings of the present study were lower than the findings of other scientists because of the Bhagnari cattle is a beef and draught breed not dairy animal same has been proved in the current study, because of low milk production. On the other hand low milk yield recorded in current study, indicates the breed genetic factors, poor nutrition and poor management at the farm.

Table 5. Mean ( \pm SEM) milk yield per lactation in Bhagnari cattle

\begin{tabular}{|c|c|c|c|}
\hline Lactation & $\begin{array}{l}\text { No. of lactation } \\
\text { observed }\end{array}$ & Milk yield(liters) Mean ( \pm SEM) & Range (liter) \\
\hline Lactation-1 & 84 & $534.7 \pm 10.846 \quad d$ & $363-977$ \\
\hline Lactation-2 & 82 & $784.4 \pm 11.045 \mathrm{c}$ & $516-991$ \\
\hline Lactation-3 & 64 & $1040.2 \pm 12.523 \mathrm{a}$ & $779-1297$ \\
\hline Lactation-4 & 46 & $923.5 \pm 14.818 \mathrm{~b}$ & $715-1159$ \\
\hline Lactation-5 & 18 & $729.3 \pm 23.429 \quad c$ & $543-910$ \\
\hline Total average & 294 & $785.78 \pm 14.53$ & $363-1297$ \\
\hline
\end{tabular}

\section{Conclusion}

It is concluded that the Bhagnari breed is low milk producer, attained late age at puberty, late age at first calving and having long calving interval and postpartum estrus period. It was observed that the Bhagnari 
breed could be reared for meat purpose and not suitable for dairy. It is suggested on the basis of the study that the reproductive herd health management program should be implemented at the farm. Out-crossing or cross breeding program should be introduced at the farm to reduce age at puberty, age at calving, calving intervals and increase in milk production of the animals of this breed.

\section{Authors' contribution}

Conceived and designed the experiments: HK Kunbhar, Performed the experiments: SM Sharif \& AA Memon, Analyzed the data: H Abro \& V Suthar, Contributed reagents/ materials/ analysis tools: GA Mughal, Wrote the paper: HK Kunbhar \& R Abro.

\section{References}

1. Government of Pakistan (2014). Pakistan Economic Survey 2013-14. Advisory wing. Finance Division, Government of Pakistan, Islamabad.

2. The Express Tribunes (2016). Moneymakers: Milk could became the country's white gold. Thursday, 26 may 2016.

3. Ahmed J (2013). Economic survey of Pakistan and Livestock sector. Economic division government of Pakistan, Islamabad. June, 2013.

4. Afzal M \& Naqvi A (2004). Livestock resources of Pakistan: Present status and future trends. Quarterly Science Vision 9(1-2/3-4):1-14.

5. Kakar MA \& Bajwa MA (2004). An overview of Livestock and dairy Development department Baluchistan, Quetta pp: 40-85.

6. Kakar MA, Abbas F, Bajwa MA, Perkash S, Hameed T, Bilal M, Sajid S \& Babar S (2005). Enhancement in the availability of red meat through high performance beef breed. Journal of applied Embryological Science. 1(2):67-8.

7. Kunbhar HK, Lasi AB \& Memon AA (2015). Reproductive performance of Crossbred cattle maintained at Nagori cattle farm, Nagori society, Karachi, Sindh, Pakistan. Journal of Advances in
Animal and Veterinary Sciences. 23 (4): 131-142.

8. Baloch HK (2005). Performance analysis of Red Sindhi Cattle under semi-intensive management at Hub, Baluchistan M. Sci, Thesis, Department Livestock Management, Sindh Agriculture University, Tandojam.

9. Kakar MA, Chaudhry RA, Ahmed N \& Khan IH (2001). Studies on the reproductive efficiency of Bhagnari cattle in Baluchistan. Pakistan Veterinary Journal. 21(1):1-7.

10. Kuthu ZH, Javeed K \& Ahmed N (2007). Productive performances of indigenous cows of Azad Kashmir. Journal of Animal and Plant Sciences. 17(3-4):47-51.

11. Qureshi MS, Khan A, Mirbahar KB \& Samo MU (2000). Productive and reproductive performance and their interaction in crossbred cattle under field condition in district Bannu, Pakistan Veterinary Journal. 20(1):31-34.

12. Ahmad B, Khan S, Manan A \& Abdullah (2007). Production and reproduction performance of Jersey Cattle at Cattle Breeding and Dairy Farm Hari Chand Charsadda N W F P. Journal of Agriculture and Biological Science. 7(2):1-5.

13. Sattar A, Mirza RH, Niazi AAK \& Latif M (2005). Productive and reproductive performance of Holstein-Friesian cows in Pakistan. Pakistan Veterinary Journal. 25(2): 75-81.

14. Belay Duguma, Kechero Y \& Janssens GPJ (2012). Productive and Reproductive Performance of Zebu X Holstein-Friesian Crossbred Dairy Cows in Jimma Town, Oromia, Ethiopia. Global Veterinaria 8(1): 67-72.

15. Aslam M, Nawaz M \& Khan MS (2002). Comparative performance of some cattle breeds under Barani conditions of Pakistan. International Journal of Agriculture \& Biology. 8(4):565-567. 
16. Rehman ZU (2006). Inter-herd performance and genetic evaluation of Sahiwal cattle in Pakistan. Ph.D. Thesis, Agriculture University, Faisalabad, Pakistan.

17. Mustafa MI, Latif M, Bashir MK \& Ahmad B (2003). Reproductive performance of Red Sindhi cattle under hot and humid environment of Baluchistan province of Pakistan. Pakistan Veterinary Journal. 23(2): 6672.

18. Sandhu ZS, Tarique MM, Baloch MH \& Quimkhani MA (2011). Performance analysis of Holstein Friesian cattle in intensive management dairy farm Quetta, Balochi tan, Pakistan. Pakistan Journal of life and Social Sciences. $9(2): 128-133$.

19.Emin M (2005). Environmental factor affecting milk yield and fertility traits of Simmental cows rose at the Kazova state
Farmland phenotypic correlation between this traits. Turkish Journal of Veterinary and Animal Sciences. 29(6):987-993.

20. Obese FY, Okemah SA, Oddly EOK \& Gyawu P (1999). Post-partum reproductive performance of Sanga cattle in smallholder peri-urban Dairy herds in the Accra Plains of Ghana. Tropical Animal Health and Production. 31(3): 181-190.

21. Haque MN, Haque MR, Parvin A \& Hussain M (2011). Production and reproductive performances of different crossbred cattle at Sylhet government dairy farm. Progressive Agriculture. 22(1\&2):47-54.

22.Bajwa IR, Khan MS, Khan MA \& Gondal KZ (2004). Environmental factor affecting milk yield and lactation length in Sahiwal cattle. Pakistan Veterinary Journal. 24:1-5. 